\title{
A new transport mechanism of biomass burning from Indochina as identified by modeling studies
}

\author{
C.-Y. Lin ${ }^{1}$, H.-m. Hsu ${ }^{2}$, Y. H. Lee ${ }^{2}$, C. H. Kuo ${ }^{3}$, Y.-F. Sheng ${ }^{1}$, and D. A. Chu ${ }^{4}$ \\ ${ }^{1}$ Research Center for Environmental Changes, Academia Sinica, Taipei, Taiwan \\ ${ }^{2}$ National Center for Atmospheric Research, Boulder, Colorado, USA \\ ${ }^{3}$ Department of Geology, Chinese Culture University, Taipei, Taiwan \\ ${ }^{4}$ Goddard Earth Sciences and Technology Center, NASA, Greenbelt, Maryland, USA
}

Received: 17 April 2009 - Published in Atmos. Chem. Phys. Discuss.: 15 June 2009

Revised: 21 September 2009 - Accepted: 23 September 2009 - Published: 21 October 2009

\begin{abstract}
Biomass burning in the Indochina Peninsula (Indochina) is one of the important ozone sources in the low troposphere over East Asia in springtime. Moderate Resolution Imaging Spectroradiometer (MODIS) data show that 20000 or more active fire detections occurred annually in spring only from 2000 to 2007. In our tracer modeling study, we identify a new mechanism transporting the tracer over Indochina that is significantly different from the vertical transport mechanism over the equatorial areas such as Indonesia and Malaysia. Simulation results demonstrate that the leeside troughs over Indochina play a dominant role in the uplift of the tracer below $3 \mathrm{~km}$, and that the strong westerlies prevailing above $3 \mathrm{~km}$ transport the tracer. These fundamental mechanisms have a major impact on the air quality downwind from Indochina over East Asia. The climatological importance of such a leeside trough is also discussed.
\end{abstract}

\section{Introduction}

The impact of biomass burning during spring over Southeast Asia on the atmospheric environment of East Asia is getting more and more attention. It is believed that the ozone precursors and aerosols produced by the biomass burning can significantly affect the air quality over downstream areas. A number of papers (e.g., Andreae et al., 1988, 1994; Crutzen and Andreae, 1990; Mauzerall et al., 1998; Poppe et al., 1998; Thompson et al., 2001; Chan et al., 2003a, b; Jourdain et al., 2007) note that the linkages between excess tropospheric ozone and biomass burning are quite strong because ozone precursors such as nitrogen oxides, carbon monoxide,

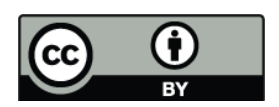

Correspondence to: C.-Y. Lin

(yao435@rcec.sinica.edu.tw) and hydrocarbons are the products of biomass burning. For East Asia, the biomass burning in Indochina has been identified as a source of significant impact on the ozone concentration in Hong Kong during spring (Chan et al., 2003a, b; Liu et al., 1999) and aerosols from such burning are one of the important sources of "Asian brown cloud" (Ramanathan and Crutzen, 2003; Ramanathan et al. 2005; Lau et al., 2008). Based on atmospheric conditions, the scale of these impacts can be regional and even global and thus can affect the regional and global climate.

It has been well documented that biomass burning frequently occurs during spring over areas of the Indochina Peninsula (Indochina) such as Thailand, Laos, Cambodia, and Vietnam (Dwyer et al., 1988; Christopher and Kimberly et al., 1996; Chan et al., 2003a). Recent progress of satellite monitoring systems, such as Along-Track Scanning Radiometer (ATSR) (Kasischke et al., 2003), Advanced Very High Resolution Radiometer (AVHRR) (Ichoku et al., 2003), and Moderate Resolution Imaging Spectroradiometer (MODIS) (Van der Werf et al., 2006; Giglio et al., 2006a, b; Boschetti et al., 2008), resulted in useful information on identifying various aspects of fire events and duration of burning.

Lin et al. (2009) illustrated an average horizontal wind speed pattern above $700 \mathrm{hPa}$ and identified a strong wind speed belt south of the Tibetan Plateau and north of $20^{\circ} \mathrm{N}$ over Indochina. They also suggested that a significant average peak of ozone concentration existed at around $4 \mathrm{~km}$ in spring that was attributed to biomass burning across Indochina. Since active fire spots occur frequently and abundantly over Indochina, the key question is how the biomassburning products are uplifted to above $3 \mathrm{~km}$ and then transported by the strong westerly wind downwind to Taiwan and even the entire East Asia. Liu et al. (2003) indicated that transport of air pollutants from the boundary layer (BL) to

Published by Copernicus Publications on behalf of the European Geosciences Union. 
the free troposphere (FT) was mainly facilitated by three mechanisms; fronts, convection, and orographic forcing over mainland China. Frontal lifting is an effective mechanism to transport surface pollutants to the FT over continents (Bethan et al., 1998), and fronts frequently occurred over China during winter and spring. Furthermore, orographic lifting over Central and Eastern China combined with cold fronts could enhance the transport significantly (Donnell et al., 2001; Liu et al., 2003).

"Deep convection" occurrence over South East (SE) Asia is the most frequently mentioned mechanism for the transport of biomass burning products upwards. Some researchers noted that the convective activity over SE Asia, together with strong thermal buoyancy and turbulence created by active fires is able to carry biomass air pollutants to higher altitudes over SE Asia (Folkins et al., 1997; Jocob et al., 1999; Chan et al., 2003a). However, so far, discussions of biomass burning in conjunction with a strong convection mechanism in previous studies are limited to the low latitude equatorial areas such as Indonesia, New Guinea, and Malaysia (Folkins, 1997; Hsu et al., 1996). In other words, the "deep convection" mechanism seems to apply only to the area around the equator due to the strong lifting from frequent and strong tropical convection. The inter-tropical convergence zone (ITCZ) can be the primary organizing contributor. For example, the studies by Folkins (1997) and Hsu et al. (1996) concerned such areas as New Guinea, Australia, Indonesia, and Malaysia. On the other hand, there is a lack of such tropical convective uplifting over Indochina during spring. Thus, it is important to identify a different mechanism responsible for the uplifting of biomass-burning products over Indochina below $3 \mathrm{~km}$. The mechanism we propose is the leeside trough at the eastern flank of the Tibetan Plateau and the mountains of Indochina. The Tibetan Plateau represents a huge obstacle that can block basic atmospheric flows, and the leeside trough can form under favorable conditions. The leeside trough plays an important role because the associated upward motion is quite significant. Once the trough is generated and associates with profound biomass burning, it would create favorable conditions for the biomass-burning products to be transported aloft. As we understand, this is the first time this mechanism is being proposed as biomass-burning transport mechanism over Indochina.

In previous studies, trajectory analyses have generally identified ozone peaks as possible air masses coming in from the low troposphere (e.g. Harris et al., 1998; Oltmans et al., 2004). However, such traditional analyses can only describe atmospheric air mass motion in part as they do not consider important physical processes (e.g. dry and wet depositions) and dynamical processes (e.g. small-scale convection and turbulent mixing). In this study, a newly developed tracer module is integrated into the Weather Research and Forecasting/Chemistry (WRF/Chem, Grell, et al., 2005) model (Ver. 3.0) and utilized in our study. We hence propose to apply this modeling system to demonstrate this newly identified transport mechanism for uplifting biomass-burning products from Indochina on the leeside of the Tibetan Plateau and the Indochina mountains.

In this report, evidences of biomass burning over Indochina are presented first, followed by case studies using data from an ozone sonde and satellites, traditional weather data, and modeling results. Additional events are also provided to suggest the simulated cases are not singular. Then, the uplifting mechanism over Indochina is identified as the leeside trough at the eastern flank of the Tibetan Plateau. Finally the mean leeside trough over a period of 60 years during the springtime is described as a prominent feature of climatological importance.

\section{Observations}

Figure 1a shows the inter-annual variation of hot spots in spring (March to May) over Indochina derived from the Collection 4, Terra MODIS satellite images with $1 \mathrm{~km}$ resolution from 2000 to 2007. The data were obtained from the Land Processes Distributed Active Archive Center (LPDAAC). Clearly, there were many fire points over Indochina in the past few years; there have been more than 20000 active fire detections annually during spring after 2004. Also, biomass-burning fire counts indicated a very remarkable seasonal variability over Indochina; active fire detections occurred mainly during the later winter and spring (Fig. 1b).

According to an ozone sounding on 11 April 2005 in Northern Taiwan (Panchiao station, $121.43^{\circ} \mathrm{E}, 24.98^{\circ} \mathrm{N}$ ), the ozone concentration in the troposphere lower than $2 \mathrm{~km}$ was less than $50 \mathrm{ppb}$ (Fig. 2a). However, there was a distinct peak of $120 \mathrm{ppb}$ around $4 \mathrm{~km}$ with high relative humidity (greater than 80\%). On the average, ozone concentrations in the lower troposphere between 3 and $6 \mathrm{~km}$ over Northern Taiwan ranged from 70 to $80 \mathrm{ppb}$ in spring (Lin et al., 2009). In other words, the ozone concentration for this episode was about $40 \mathrm{ppb}$ greater than the average at $4 \mathrm{~km}$. The peak ozone concentration around $4 \mathrm{~km}$ with high relative humidity implied that the air masses mainly came from the lower troposphere and low latitudes (Liu et al., 1999; Chan et al., 2003a).

Figure $2 b$ depicts the fire hot spots derived from MODIS satellite observations from 8 April (blue crosses) to 9 April (red dots) during the period of burning episodes when the air masses passed over South Asia (Fig. 2c, detail described in Sect. 4). Indeed, a large measure of biomass burning occurred over the Indochina region upstream of Taiwan.

The near surface $(925 \mathrm{hPa})$ weather map in Fig. 3a illustrates a chain of low pressure systems located from central to south China and Indochina. At $850 \mathrm{hPa}$, a very deep trough extended southward from northern China to Indochina around $105^{\circ} \mathrm{E}, 20^{\circ} \mathrm{N}$ (Fig. 3b). Even at $700 \mathrm{hPa}$, there still was a deep trough over southern China and Indochina (not shown). This favorable weather condition 


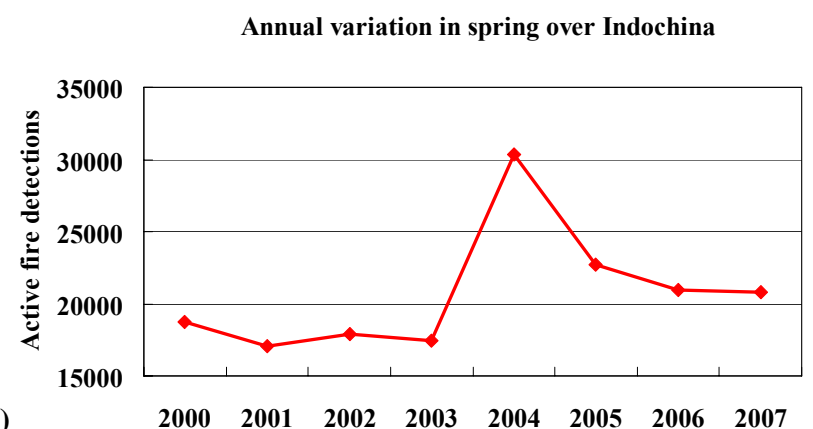

(a)

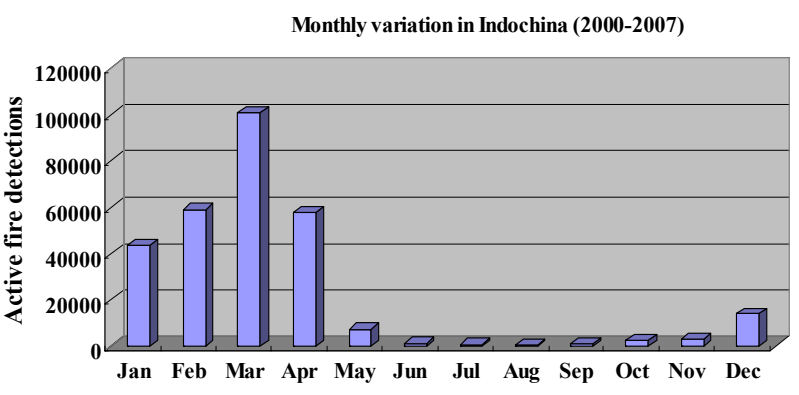

(b)

Fig. 1. (a) The annual variation of active fire detections from Terra MODIS satellite in spring (March, April, and May) over Indochina $\left(10^{\circ} \mathrm{N}\right.$ to $25^{\circ} \mathrm{N}, 90^{\circ} \mathrm{E}$ to $\left.110^{\circ} \mathrm{E}\right)$ from 2000 to 2007 (b) The seasonal variation of active fire detections in Indochina $\left(10^{\circ} \mathrm{N}\right.$ to $25^{\circ} \mathrm{N}, 9^{\circ} \mathrm{E}$ to $110^{\circ} \mathrm{E}$ ) from 2000 to 2007 .

should provide a lift for the local air masses over southern China and the Indochina region. The wind profile associated with the ozone sonde (Fig. 2a) shows that the wind direction changed to southwesterly when the elevation was greater than $1 \mathrm{~km}$, and the wind speed steadily increased to more than $15 \mathrm{~m} / \mathrm{s}$ as the altitude increased from $1 \mathrm{~km}$ to more than $3 \mathrm{~km}$. Therefore, these favorable conditions, including weather patterns and abundant biomass emissions over Indochina, provided significant opportunity for ozone to form reactively to a 4-km altitude.

\section{Trajectory and tracer/dynamic models}

In order to identify sources of the high ozone episode that occurred on 11 April 2005 and to examine how transport paths could affect the ozone concentrations profile in Northern Taiwan, the HYSPLIT (Hybrid Single-Particle LagrangianIntegrated Trajectory) model (Draxler and Hess, 1988) was used to trace the origins of the air masses. Furthermore, we employed the WRF/Chem (Ver. 3.0) (Grell et al., 2005) modeling system to identify the long-range transport associated with biomass burning over Indochina in our case study. A new tracer module, developed by us, was integrated into the WRF/Chem model and applied to identify the transport. The tracers were assigned to the fire locations derived from MODIS satellite data over Indochina ranging from 5 to $25^{\circ} \mathrm{N}$

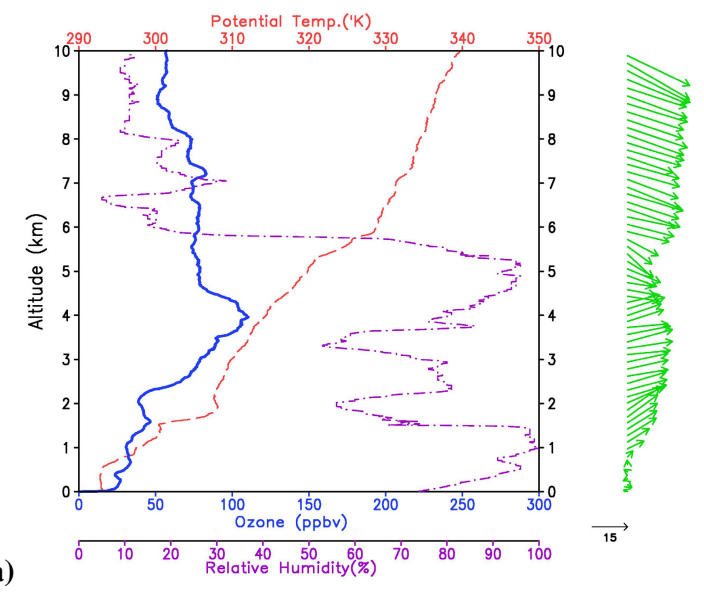

(a)

(b)

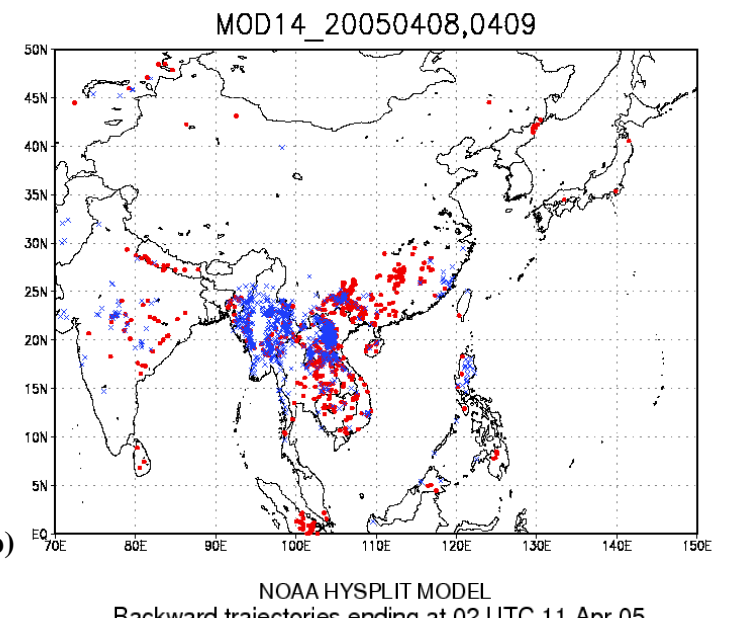

Backward trajectories ending at 02 UTC 11 Apr 05 FNL Meteorological Data

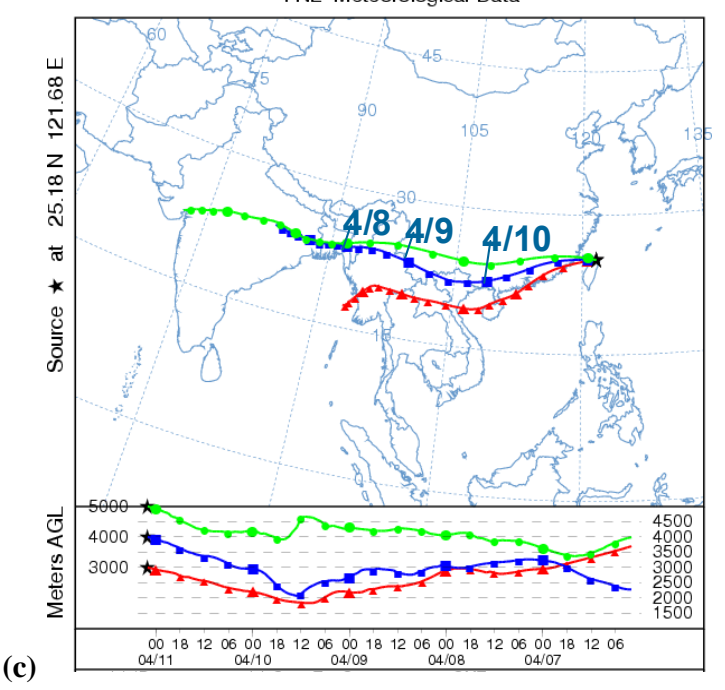

Fig. 2. (a) The vertical profile of ozone (solid), relative humidity (dash dot), potential temperature (dash), and wind field launched over Northern Taiwan (Panchiao station, $121.4^{\circ} \mathrm{E}, 24.98^{\circ} \mathrm{N}$ ) at 01:46 UTC (09:46 LST) 11 April 2005. (b) Geographical distributions of active fire detections from 8 (denoted by cross) to 9 (red dots) April 2005. (c) Result of the HYSPLIT model backward trajectory analysis started at 02:00 UTC (10:00 LST), 11 April 2005 at altitudes of 3000, 4000, and $5000 \mathrm{~m}$ at Panchiao station in Northern Taiwan. 


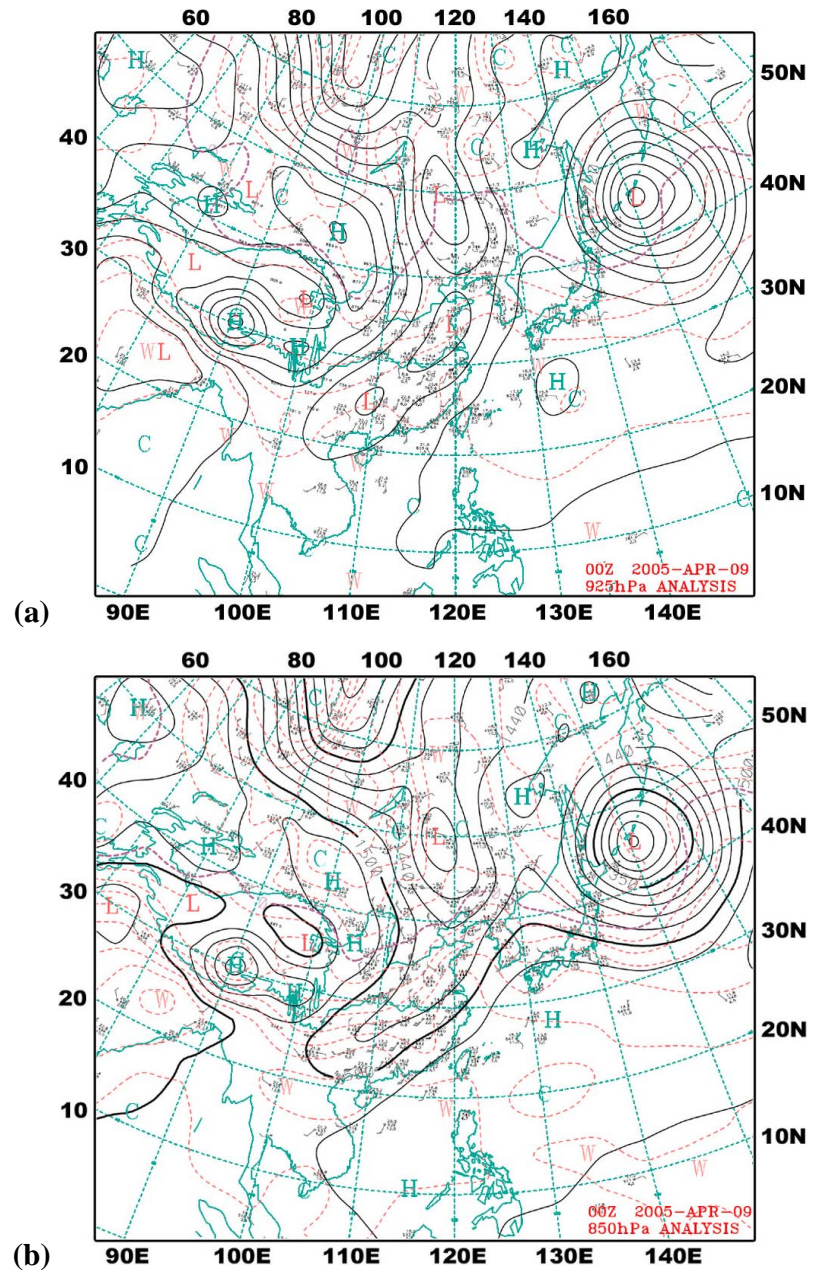

Fig. 3. The near surface weather charts from Central Weather Bureau (CWB) of Taiwan for geographic height at 00:00 UTC on 9 April 2005. Symbols of $\mathrm{H}$ and $\mathrm{L}$ show the location of major high and low pressure systems (a) $925 \mathrm{hPa}$, (b) $850 \mathrm{hPa}$.

and 90 to $110^{\circ} \mathrm{E}$. They were placed at the first level above the surface at each fire location with a concentration of 10000 units per day (416.67 units/h). The meteorological initial and boundary conditions for WRF/Chem were obtained from NCEP-FNL data sets at 6-h intervals. The Yonsei University (YSU) (Hong and Dudhia, 2003) planetary boundary layer scheme was selected in this study. The horizontal resolution for our simulations was $27 \mathrm{~km}$ and the grid box had $200 \times 200$ points in both the east-west and north-south directions. There were 35 vertical levels (the $\sigma$ levels were: 1.000 , $0.998,0.994,0.990,0.985,0.980,0.970,0.960,0.945,0.930$, $0.910,0.900,0.890,0.870,0.850,0.820,0.790,0.760,0.720$, $0.690,0.660,0.630,0.600,0.550,0.500,0.450,0.400,0.350$, $0.300,0.250,0.200,0.150,0.100,0.050,0.000)$ and the lowest level was about $20 \mathrm{~m}$ above the surface. To assure the meteorological fields were well simulated, the four-dimensional data assimilation (FDDA) scheme was activated based on the NCEP-FNL analysis data.

\section{Simulation results}

Three-day back trajectory analyses using HYSPLIT at the altitudes of $3 \mathrm{~km}, 4 \mathrm{~km}$, and $5 \mathrm{~km}$ from Northern Taiwan for the event of 11 April 2005 (Fig. 2c) suggested that the air masses in Northern Taiwan originated from major biomass burning on 8 and 9 April in Southern China, Indochina, and possibly India where burning occurred at a lower elevation than the trace layer. The air mass paths revealed that the air masses of the ozone peak layer primarily came from biomass-burning regions for this episode. The trajectory at $3 \mathrm{~km}$ was backtracked to the eastern Bay of Bengal, and it lowered to about $1.7 \mathrm{~km}$ over the Indochina burning region. The connection between the uplift from the burning surface to the steering flow at about 3-4 km requires further investigation.

According to the trajectory analysis at 3-5 km (Fig. 2c) the air masses passed over Indochina during 8 and 9 April before reaching Taiwan. To examine the impact of biomass burning on East Asia, we conducted tracer simulations with WRF/Chem with tracers placed on 8 and 9 April over the fire locations reported by the MODIS satellite. Figure 4 depicts the horizontal distribution of tracer concentration and wind field at the level of $650 \mathrm{hPa}$ (around $4 \mathrm{~km}$ ). The relatively strong wind belt (wind speed $>10 \mathrm{~m} / \mathrm{s}$ ) at $650 \mathrm{hPa}$ located just south of the Tibetan Plateau (Fig. 4a) merged into a higher-latitude strong-wind belt over East Asias marginal seas at around 01:00 UTC 9 April (Fig. 4b). Simulation successfully produced the necessary flow pattern for longrange transport. At 12:00 UTC 9 April, the high concentration tracers were transported to the coastal areas of China following the strong wind belts that extend to East Taiwan (not shown). As a consequence, the strong wind belt extended in an East-West direction after 01:00 UTC 10 April and the light tracer concentration had already reached Northern Taiwan (Fig. 4c). The elevated tracer concentration lay in northeast-southwest belts and covered Northern Taiwan at around 02:00 UTC 11 April (Fig. 4d).

To further illustrate what mechanism dominates the vertical tracer transport over Indochina, tracer and other variables are presented on a cross-section along line $\mathrm{AB}$ in Fig. 5a. Figure 5a shows the geographic locations and the terrain in Asia. Along line AB, we can see that the enhanced absolute vorticity (colored) developed to as high as $700 \mathrm{hPa}$, showing an upward motion $(>8 \mathrm{~cm} / \mathrm{s}$, white contour lines) just over the lee side of the mountain at 12:00 UTC 9 April (Fig. 5b). Actually, the enhanced absolute vorticity over the leeside lasted for the whole study period until 11 April (not shown). Concurrently, the wind speed greater than $10(15) \mathrm{m} / \mathrm{s}$ (contour line) was from $300 \mathrm{hPa}$ down to $900(800) \mathrm{hPa}$ and existed for more than 2 days (Fig. $5 \mathrm{c}-\mathrm{f}$ ). The enhanced vorticity over the southern part of the leeside trough was rather shallow (up to $700 \mathrm{hPa}$ ), and a significant upward motion occurred on the eastern side of the trough (12:00 UTC 9 April, Fig. $5 \mathrm{~b}$ and d). During the period between 8 and 11 April, the up- and down-ward motions were supported by the warm 
(a)

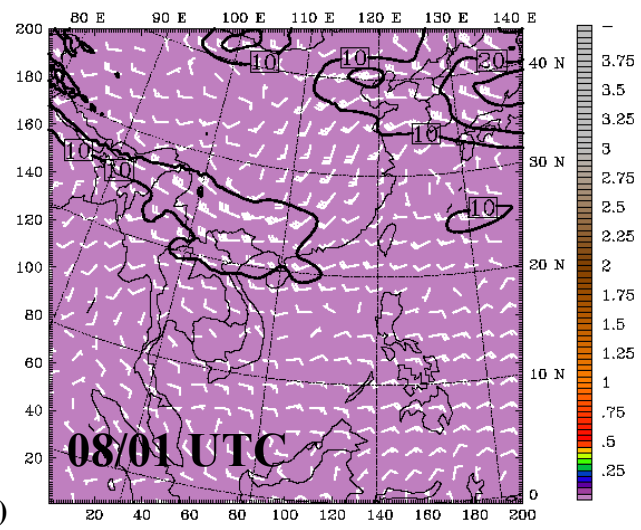

(b)

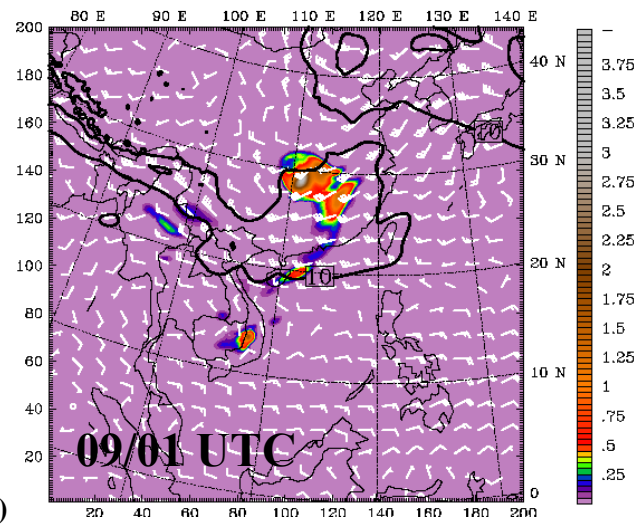

(c)
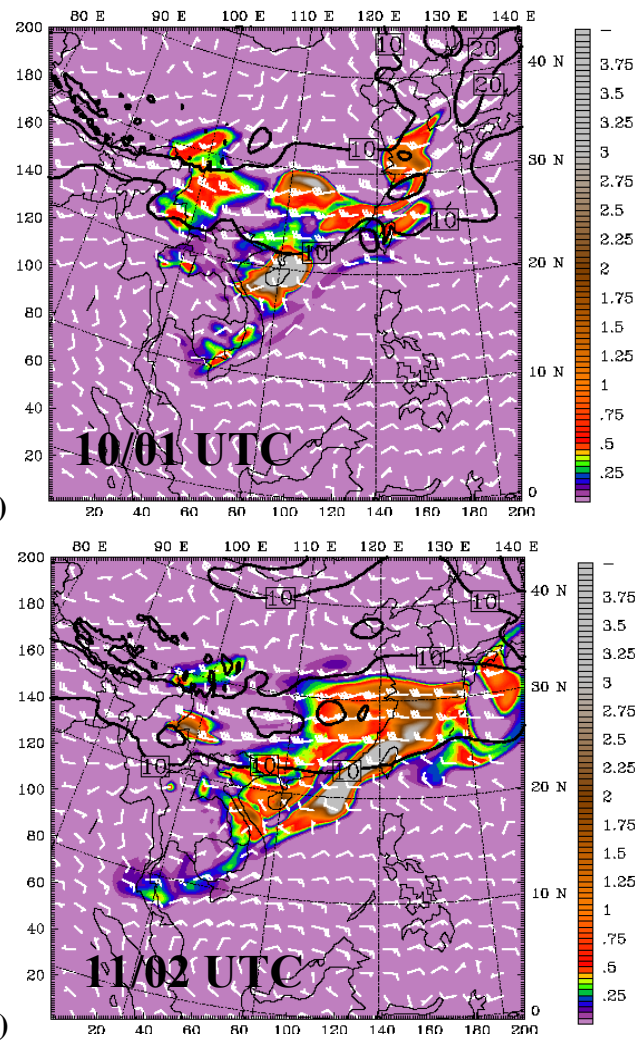

Fig. 4. Simulated distributions of tracer concentration (colored) and wind field at 650 hpa (a) 01:00 UTC 8 April 2005, (b) 01:00 UTC 9 April 2005, (c) 01:00 UTC 10 April 2005, and (d) 02:00 UTC 11 April 2005. The thick contour lines represent the wind speed starting at $10 \mathrm{~m} / \mathrm{s}$ and at $10 \mathrm{~m} / \mathrm{s}$ interval. (a)

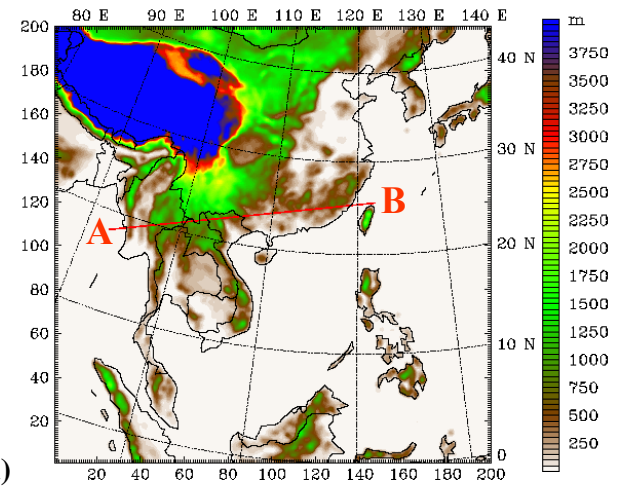

(b)
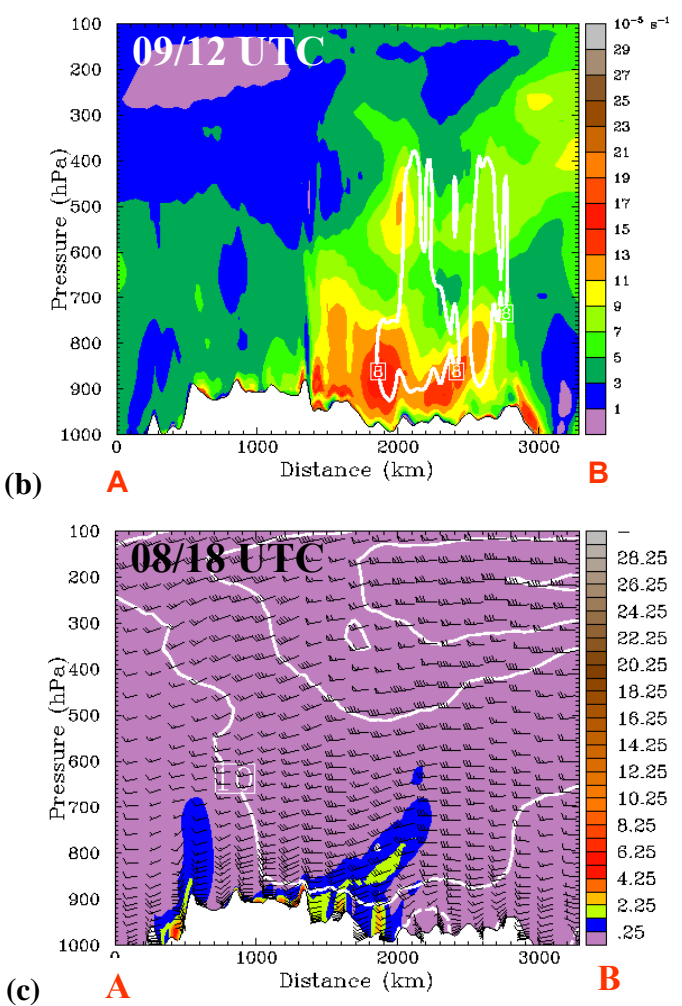

Fig. 5. (a) The geographic locations of East Asia and the terrain in Asia. Line AB displays the location of the East-West cross section in Fig. 5b-f. (b) The East-West cross section at line AB in Fig. 5a at 12:00 UTC 9 April 2005. The colored area represents the amount of absolute vorticity. The vertical velocity equals $8 \mathrm{~cm} / \mathrm{s}$ and is denoted by a solid white line. (c) The vertical distribution of tracer concentration (colored) and wind field along cross section line $\mathrm{AB}$ at 18:00 UTC 8 April 2005. The solid contours are the westerly wind speed and equal $10 \mathrm{~m} / \mathrm{s}$ and at $10 \mathrm{~m} / \mathrm{s}$ interval. The dashed line represents $0 \mathrm{~m} / \mathrm{s}$. (d) Same as Fig. 5c but for 12:00 UTC 9 April 2005. (e) Same as Fig. 5c but for 18:00 UTC 9 April 2005. (f) Same as Fig. 5c but for 02:00 UTC 11 April 2005. (g) Simulated vertical distribution of tracer concentration for different dates (12:00 UTC 10 April, 18:00 UTC 10 April, 00:00 UTC 11 April, 02:00 UTC 11 April, and 02:00 UTC 14 April 2005) over Northern Taiwan. 


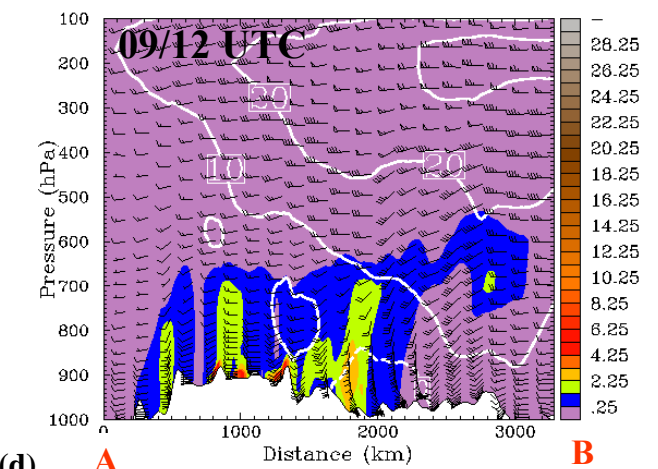

(d)

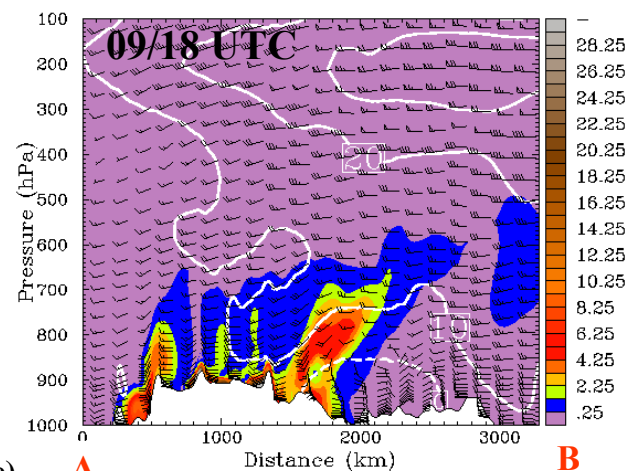

(e)

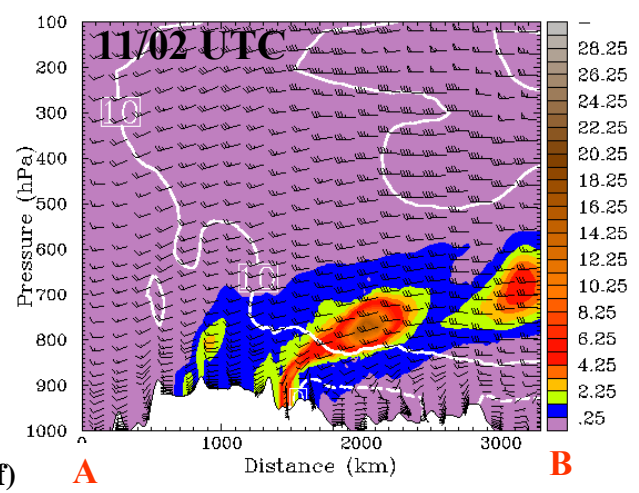

(f) $\mathrm{A}$

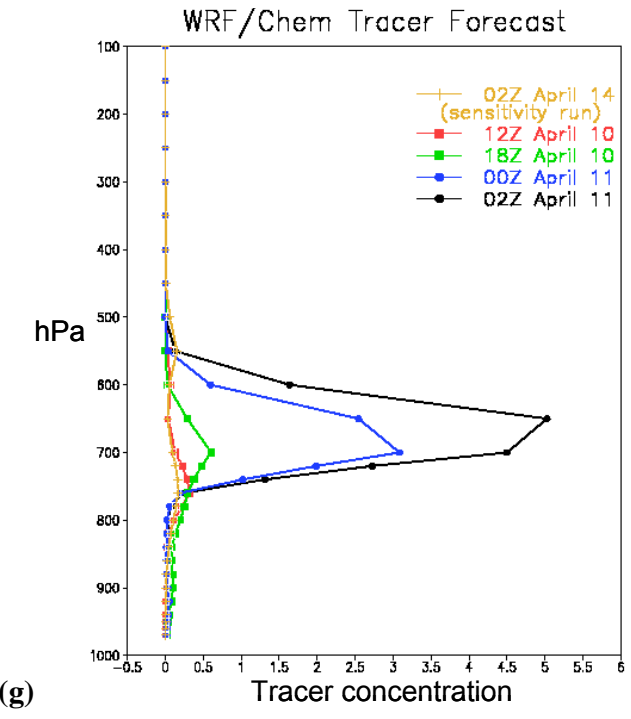

(g)

Fig. 5. Continued. advection on the eastern side of the lee trough and the cold advection on the western side, respectively. Such synopticscale relationship can be realized through the omega equation under the quasi-geostrophic dynamics (Holton, 2004; Chap. 6). Further interesting synoptic- and meso-scale evolutions and their dynamics will be discussed elsewhere later.

The upward motion carried the tracers as high as $700 \mathrm{hPa}$ (Fig. 5c-e). After the tracers be uplifted to a high elevation and then followed the strong winds to the downwind areas (Fig. 5e-f). Obviously, the existence of the leeside trough played a dominant role in uplifting the tracers to the high altitude. After that, the tracers were carried away from the source area to downwind Taiwan and even East Asia by the strong westerly wind. The leeside trough and strong prevailing wind provide favorable weather conditions for the transport of tracers to the downstream areas.

Figure $5 \mathrm{~g}$ shows the vertical distribution of the tracer concentration from the WRF/Chem simulation at Panchiao station over Northern Taiwan at different times. In general, the peak of the tracer concentration was around $650 \mathrm{hPa}$ ( $\sim 4000 \mathrm{~m}$ ) from 12:00 UTC 10 April to 02:00 UTC 11 April. As shown in Figs. 4 and 5c-f, the highest peak of the hourly tracer concentration was around $650 \mathrm{hPa}$ over Northern Taiwan, which agrees with the ozone sounding measurement at 02:00 UTC 11 April (Fig. 2a). The modeled results identify the long-range transport of the trace species as following the strong westerly wind from the biomass burning source areas, i.e. from South Asia and Indochina.

The above-discussed case was not the only event; two more events (20 April 2005 and 6 May 2005) were identified. Figure 6 a shows the average ozone profile for the 3 cases with significant ozone peak (about $95 \mathrm{ppb}$ ) around $4 \mathrm{~km}$ during our measurement programs in the spring of 2004 and 2005. The average weather map (the 850 -hPa geo-potential height) for these 3 cases clearly shows a significant leeside trough over Indochina (Fig. 6b) based on the NCEP/NCAR reanalysis. Among these 3 cases, the one on 11 April 2005, which we simulated, had the highest ozone peak (120 ppb) during our intensive measurement period.

\section{Sensitivity study}

To further examine the role of the leeside trough formation in tracer transport, a case on 14 April 2005 with no significant trough presence was studied. According to weather maps a high pressure system dominated over southern China and Indochina at $850 \mathrm{hPa}$ (Fig. 7a) with no significant trough at levels 850 and $700 \mathrm{hPa}$ (not shown). The observed vertical profiles (Fig. 7b) over Northern Taiwan showed an almost uniform ozone distribution, a two-layer structure as to relative humidity (moist below $4 \mathrm{~km}$ and dry above upto $7.5 \mathrm{~km}$ ), and a stable troposphere with a mixed layer below $1 \mathrm{~km}$. We further utilized the HYSPLIT model to trace back the air parcels (Fig. 7c) and found the parcels traversed north of Indochina 
(a)
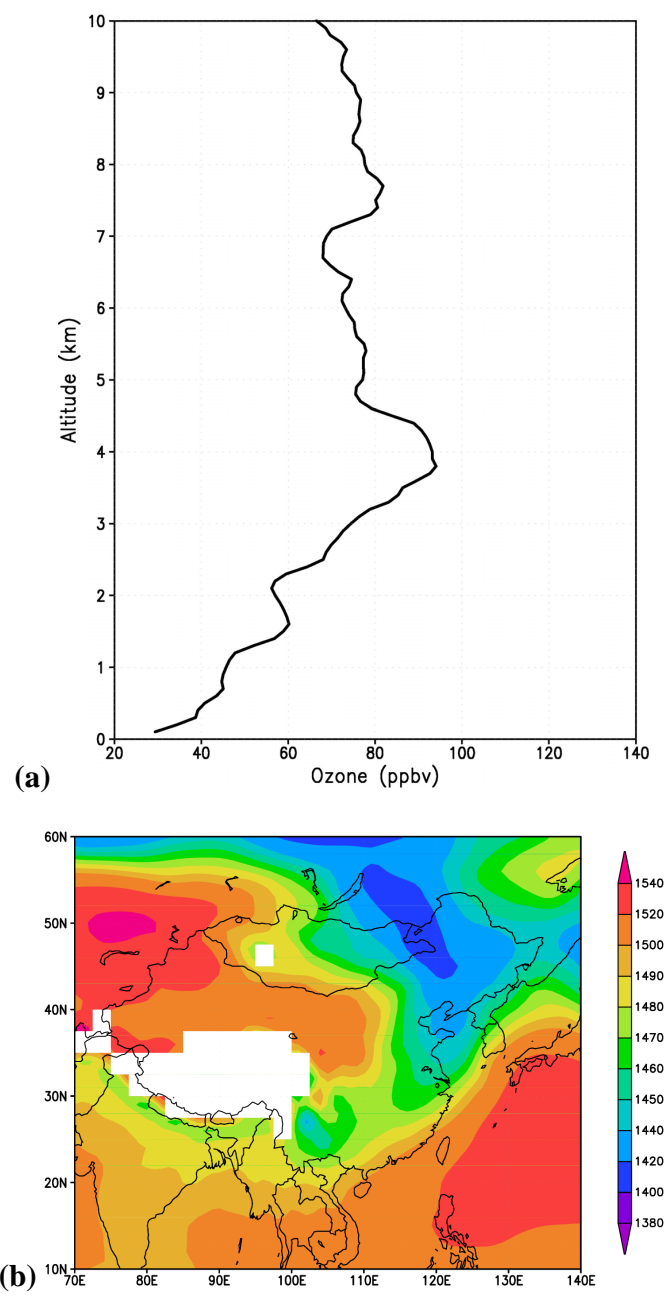

Fig. 6. (a) Averaged ozone profiles observed on 11 April, 20 April, and 6 May 2005, based on the measurements from ozone sondes. (b) Averaged 850-hPa geo-potential height based on the NCEP/NCAR reanalysis datasets for 11 and 20 April, and 6 May 2005.

in the westerlies. Without the presence of the leeside trough, there was a lack of the synoptic-scale upward motion necessary to lift the biomass burning pollutants to the levels where the westerlies prevail. Consequently, there should be no pollutant downstream toward East Asia. Another simulation, using the same configuration in the WRF/Chem for the case discussed in the previous section, was conducted. No significant peak appeared in either the tracer vertical distribution over Northern Taiwan (Fig. 5g, line with crosses) or the horizontal distribution at $650 \mathrm{hPa}$ (Fig. 7d). The contrasts between the ozone and non-ozone events are obvious in both measurements and model results.

Furthermore, 2 additional events (1 and 17 April 2005) with almost uniform ozone in the vertical profiles and no leeside trough were provided. The average vertical profile of ozone from ozone sondes exhibits the ozone was less

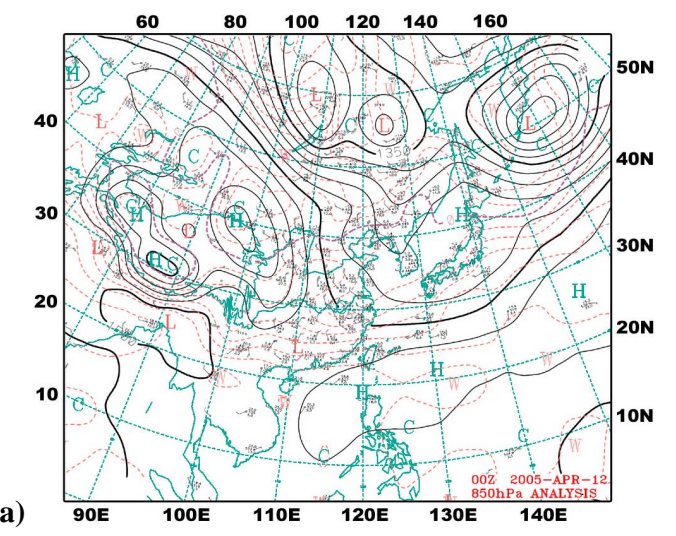

(a)

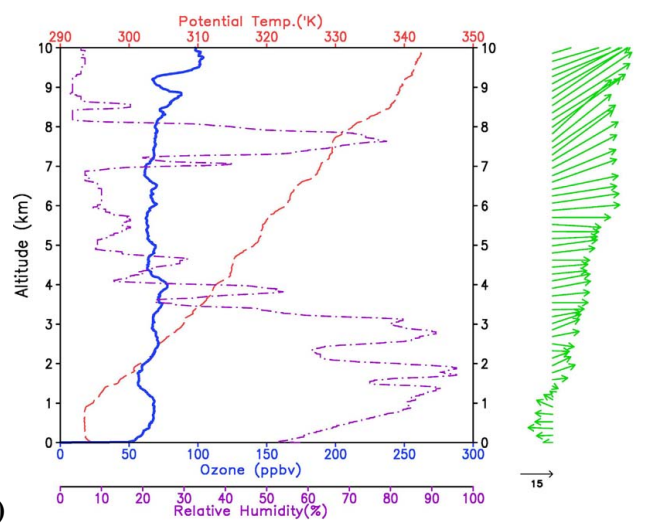

(b)

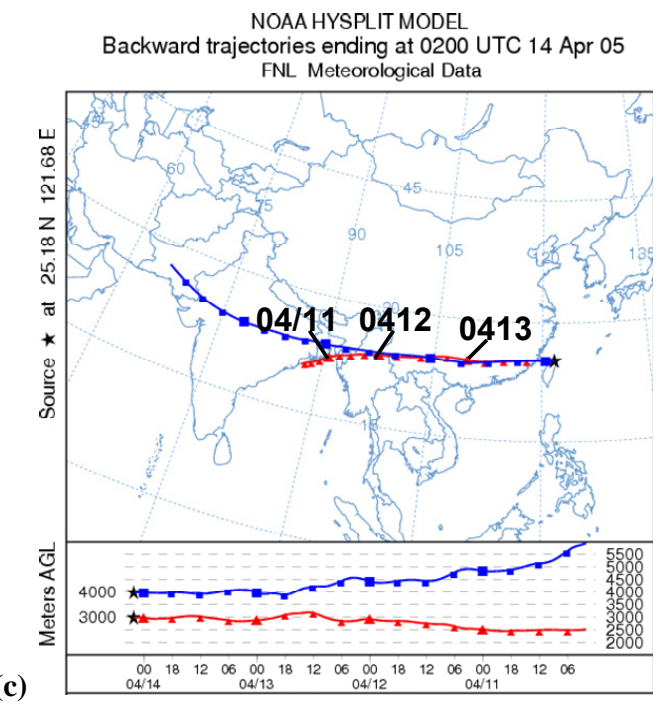

Fig. 7. (a) The $850-\mathrm{hPa}$ weather charts from Central Weather Bureau (CWB) of Taiwan at 00:00 UTC on 12 April 2005. Symbols H and $\mathrm{L}$ show the location of major high and low pressure systems. (b) The vertical profile of ozone (solid), relative humidity (dash dot), potential temperature (dash), and wind field launched over Northern Taiwan (Panchiao station, $121.4^{\circ} \mathrm{E}, 24.98 \circ \mathrm{N}$ ) at 01:46 UTC (09:46 LST) 14 April 2005. (c) Result of the HYSPLIT model backward trajectory analysis started at 02:00 UTC (10:00 LST), 14 April 2005 at altitudes of 3000 and $4000 \mathrm{~m}$ at Panchiao station in Northern Taiwan. (d) Simulated distributions of tracer concentration (colored) and wind field at $650 \mathrm{hpa}$ on 02:00 UTC 14 April 2005. The thick contour lines represent the wind speed starting at $10 \mathrm{~m} / \mathrm{s}$ and at $10 \mathrm{~m} / \mathrm{s}$ interval. 
(d)

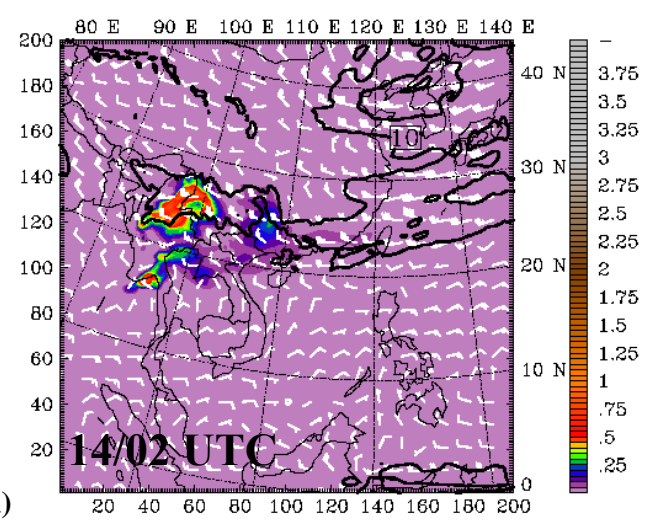

Fig. 7. Continued.

(a)
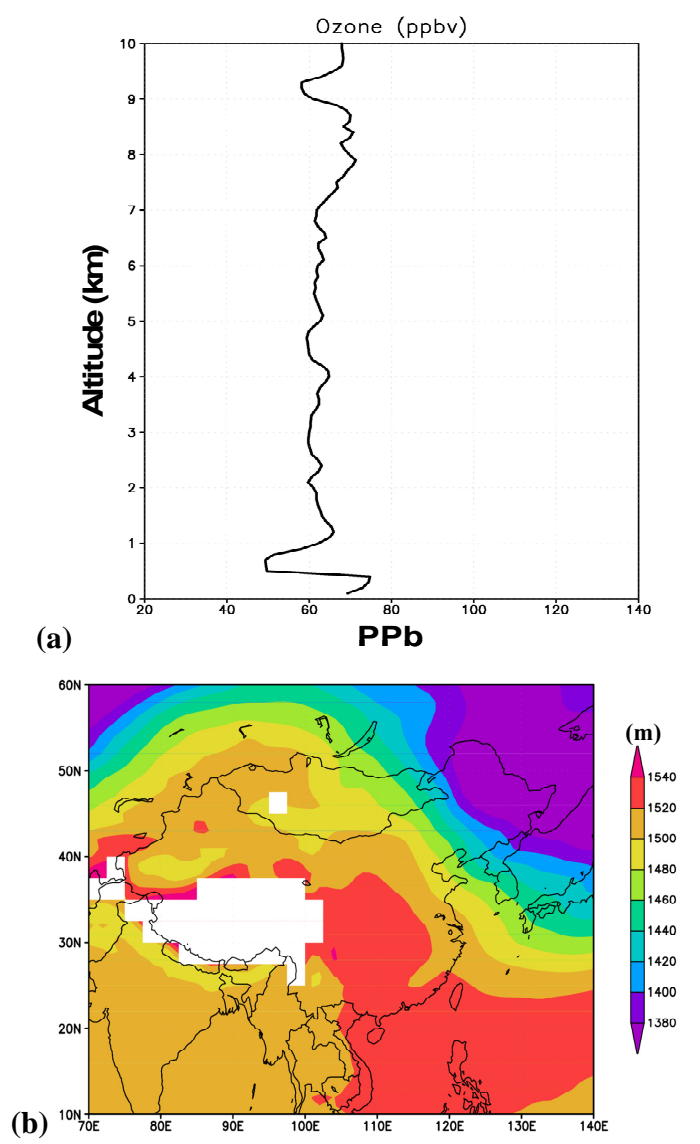

Fig. 8. (a) Averaged ozone profiles observed on 1, 14, and 17 April 2005, based on the measurements from ozone sondes. (b) Averaged 850-hPa geo-potential height based on the NCEP/NCAR reanalysis datasets for 1, 14, and 17 April 2005.

than $70 \mathrm{ppb}$ except for that in the lowest $0.5 \mathrm{~km}(>70 \mathrm{ppb})$ (Fig. 8a). Based on the NCEP/NCAR reanalysis, the averaged 850-hPa geopotential height map indicates a broad high pressure system in most of China and the Indochina region (Fig. 8b), and no trough was observed anywhere except over the southern Japan area.

\section{Discussion}

Convective activity is a mechanism popularly recognized for the injection of forest fire plumes to high altitudes (e.g. Westphal and Toon, 1991; Fromm et al. 2003; Colarco et al., 2004). However, the degree of the injection and the application of this mechanism are strongly related to weather conditions and geographic locations. For example, Labonne et al. (2007) studied the injection height of biomass burning aerosols by using the spaceborne lidar and concluded that most of these aerosols were injected within the mixing layer, except for high-latitudes areas. As mentioned earlier, previous studies indicated that the convective activity over SE Asia together with strong thermal buoyancy by active fires carried biomass burning products to higher altitudes. We already pointed out in the Introduction that convective activity does not frequently occur in Indochina except around the equator (e.g. ITCZ) in SE Asia. Especially during dry seasons over Indochina from March to May (Chan et al., 2003a), wet convection will not be the major force. Thus the next question is: is it possible that the biomass fire plumes can lift the emissions to above $3 \mathrm{~km}$ over Indochina depending only on thermal buoyancy? Actually, the theoretical plume rise height only shows a few hundred meters under stable or neutral conditions (assume buoyancy flux parameter $F b=100 \sim 1000 \mathrm{~m}^{4} \mathrm{~s}^{-3}$, wind speed: $10 \mathrm{~m} / \mathrm{s}$ ) if we use the Briggs equations (Arya, 1999). Nopmongcol U. (http://www.crwr.utexas.edu/gis/ gishydro03/Classroom/trmproj/Nopmongcol/report.htm) studied the plume rise for forest fires during the Texas Air Quality Study period by using the ArcGIS modeling tool, and found a similar trend for plume rise with a low altitude at night time and a peak during the late afternoon (only a few hundred meters) from three wild fire events. The peak plume rise height was in the range of $800-1300 \mathrm{~m}$ over Texas in his study. Therefore, even though the highest topographic elevation is nearly $1000 \mathrm{~m}$ (cross section topographic in Fig. 5b) over Indochina, additional forcing is needed for a large amount of biomass burning products to be lifted to above $3 \mathrm{~km}$. Therefore, we believe the leeside trough east of the Tibetan Plateau and the Indochina mountains is one of the major contributors, at least, for uplifting the biomass burning products from Indochina into the westerlies.

\section{Mean leeside trough}

The mechanism we propose in this study is the uplifting by the leeside trough at the eastern flank of the Tibetan Plateau and the mountains over Indochina. The Tibetan Plateau represents a huge obstacle which can block basic atmospheric flows and split the prevailing westerlies into the northern and southern branches (Yeh, 1950; Staff Member, 1957). The interaction between the westerly flow and the Tibetan Plateau causes the production of shallow vortices in the lee of the 
Plateau (Staff Member, 1958; Wu et al., 1985; Wang and Orlanski, 1987; Wang et al., 1993; Chang et al., 2000; Yasunari and Miwa, 2006). These vortices are obviously related to the leeside trough, and their relationship with the trough will be discussed later in a separate report.

The leeside trough is the dominate feature over southern China and Indochina. The associated upward motion and the low-level southerly flow provide the uplift and northward movements for the biomass-burning products at the surface. For the spring (March, April, and May) average between 1948 and 2008 using the NCEP/NCAR reanalysis dataset, this feature appears to be persistent at the eastern flank of the Tibetan Plateau at $850 \mathrm{hPa}$ (Fig. 9a), and only extends from surface to $700 \mathrm{hPa}$. The vertical motion field at $925 \mathrm{hPa}$ (Fig. 9b) supports the leeside trough, with a broad region of the upward motion extending southward over Indochina. Moreover, the vertical cross-sections of the vertical motion (Fig. 9c) and the meridional flow along $105^{\circ} \mathrm{E}$ (Fig. 9d) indicate that the trough is really shallow (below $700 \mathrm{hPa}$ ), that the north-south range of the upward motion extends for more than 20 degrees (from $15^{\circ} \mathrm{N}$ to $35^{\circ} \mathrm{N}$ ), and that the southerly flow also prevails for more than 20 degrees (between $10^{\circ} \mathrm{N}$ to $30^{\circ} \mathrm{N}$ ) with a peak speed of $5 \mathrm{~m} / \mathrm{s}$ at $850 \mathrm{hPa}$.

Based on the conservation of the potential-vorticity, a trough is frequently and easily formed at the leeside of major mountains under favorable conditions (Gill, 1982; Holton, 2004). The leeside trough plays an important role as it associates a significant upward motion. It is important to note that the effect of the leeside trough provides an important process for the tracer to be uplifted. Once the trough is generated and associates with abundant biomass burning, it would be favorable for the biomass-burning products to be transported aloft. The existence of such a trough can be seen as the most important lifting mechanism for the average ozone peak to be observed at around $4 \mathrm{~km}$ in Northern Taiwan.

\section{Conclusions}

In this study we analyzed the seasonal variability of biomass fire events from the MODIS data over Indochina and examined the tracer transport mechanism by a newly developed tracer module in the WRF/Chem model. Satellite data show nearly 20000 active fire detections per year from 2000 to 2007 over Indochina. Seasonal variation statistics indicate that biomass fires occurred most frequently during the late winter and spring over Indochina and hence they had a significant impact on the ozone concentration of downwind Taiwan and even that of East Asia. Based on the WRF/Chem tracer transport simulation results, we found that the existence of the mountain leeside trough can be the most important mechanism for tracers to be transported from the surface to above $3 \mathrm{~km}$. Based on our data analyses and models simulations, both ozone and non-ozone events support our proposal: the presence of the upward warm advection associated
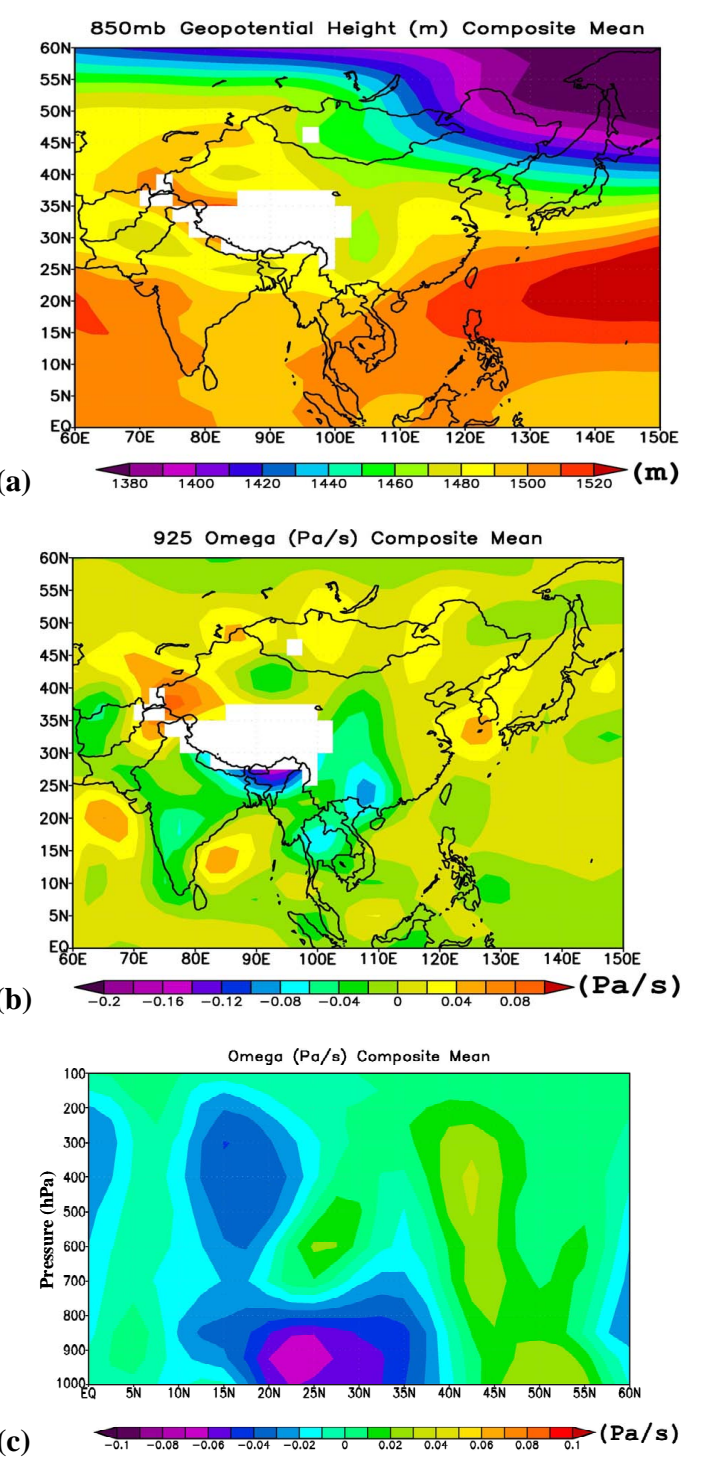

(c)

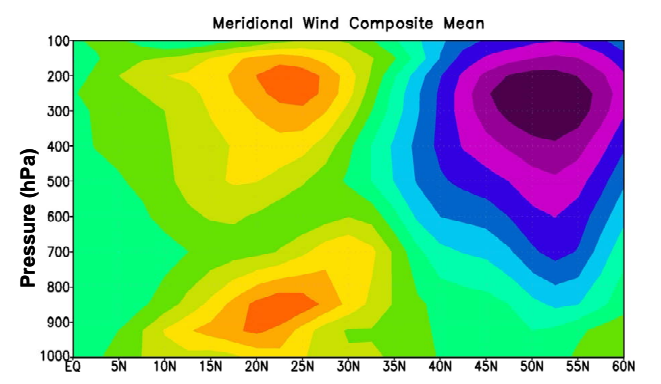

(d)

Fig. 9. (a) The average geo-potential height during the spring months (March, April, and May) between years 1948 and 2008 deduced from NCEP/NCAR reanalysis at $850 \mathrm{hPa}$. (b) Same as Fig. 9a except for the vertical motion in the pressure coordinate at $925 \mathrm{hPa}$ (unit: $\mathrm{Pa} / \mathrm{s}$ ). (c) The meridional cross section along $105^{\circ} \mathrm{E}$ for the pressure-coordinate vertical motion (unit: $\mathrm{Pa} / \mathrm{s}$ ). (d) Same as Fig. 6c except for the wind speed (unit: $\mathrm{m} / \mathrm{s}$ ). 
with the leeside trough east of the Tibetan Plateau and Indochina mountains supports the synoptic-scale uplifting of the biomass burning products into the westerlies for further downstream transport. Previously, studies commonly indicated the thermal buoyancy and turbulence created by active fires as the primary mechanism for pollutants to be transported. Over Indochina, such strong convection of tropical type did not prevail during spring; it would be too weak for the pollutants to be transported above $3 \mathrm{~km}$. The existence of the leeside trough over Indochina reasonably provides a linkage between biomass burning in Indochina and the peak ozone concentration at about $4 \mathrm{~km}$ over downwind Northern Taiwan.

Acknowledgements. This work was supported by NSC-2111M-001-004-MY3. HmH enjoyed the hospitality provided by AC/RCEC during his visits. Discussion with Richard Routunno is very much appreciated. The authors gratefully acknowledge the NOAA Air Resources Laboratory (ARL) for the provision of the HYSPLIT transport and dispersion model and/or READY website (http://www.arl.noaa.gov/ready.html) used in this publication.

Edited by: B. N. Duncan

\section{References}

Aray, S. P.: Air Pollution Meteorology and Dispersion, Oxford University Press, 1999.

Andreae, M. O., Browell, E. V., Garstang, M., et al.: Biomassburning emission and associated haze layers over Amazonia, J. Geophys. Res., 93, 1509-1527, 1988.

Andreae, M. O., Anderson, B. E., Blake, D. R., et al.: Influence of plumes from biomass burning on atmospheric chemistry over the equatorial and tropical South Atlantic during CITE 3, J. Geophys. Res., 99, 12793-12808, 1994.

Bethan, S., Vaughan, G., Gerbig, C., Volz-Thomas, A., Richer, H., and Tiddeman, D. A.: Chemical air mass differences near fronts, J. Geophys. Res., 103, 13413-13434, 1998.

Boschetti, L., Roy, D., and Justice, C.: Using NASAs World Wind Virtual Globe for Interactive Visualization of the Global MODIS Burned Area Product, Int. J. Remote Sens., 29(11), 3067-3072, 2008.

Chan, C. Y., Chan, L. Y., Harris, J. M., et al.: Characteristic of biomass burning emission sources, transport, and chemical speciation in enhanced springtime tropospheric ozone profile over Hong Kong, J. Geophys. Res., 108, 4015, doi:10.1029/2001JD001555, 2003a.

Chan, C. Y., Chan, L. Y., Chang, W. L., Zheng, Y. G., Cui, H., Zheng, X. D., Qin, Y., and Li, Y. S.: Characteristic of a tropospheric ozone profile and implications o $\mathrm{n}$ the origin of ozone over subtropical China in spring 2001, J. Geophys. Res., 108(D20), 8800, doi:10.1029/2003JD003427, 2003b.

Chang, C. P., Yi, L., George, T., and Chen, J.: A numerical simulation of vortex development during the 1992 East Asian summer monsoon onset using the Navys regional model, Mon. Weather Rev., 128, 1604-1631, 2000.
Christopher, D. E. and Kimberly, E. B.: Survey of fires in Southeast Asia and India during 1987, in: Global Biomass burning, edited by: Levine, J., MIT Press, Cambridge, Mass vol. 2,, 663-670, 1996.

Colarco, P. R., Schoeberl, M. R., Doggridge, B. G., Marufu, L. T., Torres, O., and Welton, E. J.: Transport of smoke from Canadian forest fires to the surface near Washington, D. C.: Injection height, entrainment, and optical properties, J. Geophys. Res., 109, D06203, doi:10.1029/2003JD004248, 2004.

Crutzen, P. J. and Andreae, M. O.: Biomass burning in the tropics: impact on atmospheric chemistry and biogeochemical cycles, Science, 250, 1669-1678, 1990.

Donnell, E. A., Fish, D. J., Dicks, E. M., and Thorpe, A. J.: Mechanisms for pollutant transport between the boundary layer and the free troposphere, J. Geophys. Res., 106, 7847-7856, 2001.

Draxler, R. R. and Hess, G. D.: An overview of the Hysplit-4 modeling system for trajectories, dispersion, deposition, Aust. Meteorol. Mag., 47, 295-308, 1998.

Dwyer, E., Gregoire, J. M., and Malingreau, J. P.: A global analysis of vegetation fires using satellite images: Spatial and temporal dynamics, AMBIO, 27, 175-181, 1998.

Fromm, M. D. and Seryranckx, R.: Transport of forest fire smoke above the tropopause by supercell convection, Geophys. Res. Lett., 30(10), 1542, doi:10.1029/2002GL016820, 2003.

Folkins, A. R., Chatfield, D., Baumgardner, D., and Proffitt, D.: Biomass burning and deep convection in southeastern Asia: Results from ASHOE/MAESA, J. Geophys. Res., 102, 1329113299, 1997.

Gill, A. E.: Atmosphere-Ocean Dynamics, Academia Press, New York, 662 pp., 1982.

Giglio, L., Csiszar, I., and Justice, C. O.: Global distribution and seasonality of active fires as observed with the Terra and Aqua moderate Resolution Imaging Spectroradiometer (MODIS) Sensors, J. Geophys. Res., 111, G02016, doi:10.1029/2005JG000142, 2006a.

Giglio, L., van der Werf, G. R., Randerson, J. T., Collatz, G. J., and Kasibhatla, P.: Global estimation of burned area using MODIS active fire observations, Atmos. Chem. Phys., 6, 957-974, 2006b, http://www.atmos-chem-phys.net/6/957/2006/.

Grell, G. A., Steven, E. P., and Rainer, S.: Fully coupled "online" chemistry within the WRF model, Atmos. Environ., 39, 69576975, 2005.

Harris, N., Oltmans, R. S. J., Dlugokencky, E. J., Novelli, P. C., Johnson, B. J., and Mefford, T.: An investigation into the source of the springtime troposphere ozone maximum at Mauna Loa Observatory, Geophys. Res. Lett., 25, 1895-1898, 1998.

Holton, J. R.: An Introduction to Dynamic Meteorology, 4th edn., Academic Press, 535 pp., 2004.

Hong, S.-Y. and Dudhia, J.: Testing of a new non-local boundary layer vertical diffusion scheme in numerical weather prediction applications, 16th Conference on Numerical Weather Prediction, Seattle, WA, 2003.

Hsu, N. C., Herman, J. R., Bhartia, P. K., and Seftor, C. J.: Detection of biomass burning smoke from TOMS measurements, Geophys. Res. Lett., 23, 745-748, 1996.

Ichoku, C., Kaufman, Y. J., Giglio, L., Li, Z., Fraser, R. H., Jin, J. Z., and Park, W. M.: Comparative analysis of daytime fire detection algorithms using AVHRR data for the 1995 fire season in Canada: perspective for MODIS, Int. J. Remote Sens., 24, 
1699-1690, 2003.

Jocob, D. M.: Transport and chemical evolution over the Pacific (TRACE-P): A NASA/GTE aircraft mission white paper prepared for the Global Tropospheric Experiment (GTE) of the National Aeronautics and Space Administration (NASA), available at: http://www-as.harvard.edu/chemistry/trop/tracep/ whitepaper/text.html, 1999.

Jourdain, L., Worden, H. M., Worden, J. R., et al.: Tropospheric vertical distribution of tropical Atlantic ozone observed by TES during the northern African biomass burning season, Geophys, Res. Lett., 34, L04810, doi:10.1029/2006GL028284, 2007.

Kasischke, E. S., Hewson, J. H., Stocks, B., Werf, G. V. D., and Randerson, J.: The use of ATSR active fire counts for estimating relative patterns of biomass burning: a study from the boreal forest region, Geophys. Res. Lett., 30(18), 1969, doi:10.2029/2003GL017859, 2003.

Labonne, M., Bréon, F. M., and Chevallier, F.: Injection height of biomass burning aerosols as seen from a spaceborne lidar, Geophys. Res. Lett., 34, L11806, doi:10.1029/2007GL029311, 2007.

Lau, K.-M., Ramanathan,V., Wu, G.-X., Li, Z., Tsay,S. C., et al.: The joint aerosol-monsoon experiment: A new challenge for monsoon climate research, B. Am. Meteorol. Soc., 89, 369-383, 2008.

Lin, C. Y., Chang, C. C., Chan, C. Y., Kuo, C. H., Chen, W. C., Chu, D. A., and Liu, S. C.: Characteristics of springtime profiles and sources of ozone in the low troposphere over Northern Taiwan, Atmos. Environ., accepted, 2009.

Liu, H., Chang, W. L., Oltmans, S. J., Chan, L. Y., and Harris, J. M.: On springtime high ozone events in the lower troposphere from southeast Asian biomass burning, Atmos. Environ., 33, 24932410, 1999.

Liu, H., Jacob, D. J., Bey, I., Yantosca, R. M., Ducan, B. N., and Sachse, G. W.: Transport pathways for Asian pollution outflow over the Pacific: Interannual and seasonal variations, J. Geophys. Res., 108(D20), 8786, doi:10.1029/2002JD003102, 2003.

Mauzerall, D. L., Logan, J. A., Jacob, D. J., et al.: Photochemistry in biomass burning plumes and implications for tropospheric ozone over the tropical South Atlantic, J. Geophys. Res., 103(D7), 8401-8423, 1998.

Oltmans, S. J., Johnson, B. J., Harris, J. M., and Thompson, A. M.: Tropospheric ozone over the Northern Pacific from ozonesonde observations, J. Geophys. Res., 109, D15S01, doi:10.1029/2003JD003466, 2004.
Poppe, D., Koppmann, R., and Rudolph, J.: Ozone formation in biomass burning plumes: Influence of atmospheric dilution, Geophys. Res. Lett., 25(20), 3823-3826, 1998.

Ramanathan, V. and Crutzen, P. J.: New directions: Atmospheric brown clouds, Atmos. Environ., 37, 4033-4035, 2003.

Ramanathan, V., Chung, C., Kim, D., Bettge, T., Buja, L., Kiehl, J. T., Washington, W. M., Fu, Q., Sikka, D. R., and Wild, M.: Atmospheric brown clouds: Impact on South Asian climate and hydrologic cycle, P. Natl. Acad. Sci. USA, 102, 5326-5333, 2005.

Staff Members, Academia Sinica: On the general circulation over Eastern Asia (I), Tellus, 9, 432-446, 1957.

Staff Members, Academia Sinica: On the general circulation over Eastern Asia (II), Tellus, 10, 58-75, 1958.

Thompson, A. M., Witte, J. C., Hudson, R. D., Guo, H., Herman, J. R., and Fujiwara, M.: Tropical tropospheric ozone and biomass burning, Science, 291, 2128-2132, 2001.

van der Werf, G. R., Randerson, J. T., Giglio, L., Collatz, G. J., Kasibhatla, P. S., and Arellano Jr., A. F.: Interannual variability in global biomass burning emissions from 1997 to 2004, Atmos. Chem. Phys., 6, 3423-3441, 2006, http://www.atmos-chem-phys.net/6/3423/2006/.

Wang, W., Kuo, Y. H., and Warner, T. T.: A diabatically driven mesoscale vortex in the lee of the Tibetan Plateau, Mon. Weather Rev., 121, 2542-2561, 1993.

Wang, B. and Orlanski, I.: Study of a heavy rain vortex formed over the eastern flank of Tibetan Plateau, Mon. Weather Rev., 115, 1370-1393, 1987.

Westphal, D. L. and Toon, O. B.: Simulations of microphysical, radiative, and dynamical processes in a continental-scale forest fire smoke plume, J. Geophys. Res., 96, 22379-22400, 1991.

Wu, G. X. and Chen, S. J.: The effect of mechanical forcing on the formation of a mesoscale vortex, Q. J. Roy. Meteor. Soc., 111, 1049-1070, 1985.

Yasunari, T. and Miwa, T.: Convective cloud systems over the Tibetan Plateau and their impact on meso-scale disturbances in the Meiyu/Baiu frontal zone-A case study in 1998, J. Meteorol. Soc. Jpn., 84, 783-803, 2006.

Yeh, T.-C.: The circulation of high troposphere over China in winter of 1945-1946, Tellus, 2, 173-183, 1950. 